\title{
Determination of BTEX Pollutants in Ambient Air of The Holy City of Makkah
}

\author{
T. Habeebullah and M. A. Hassanien ${ }^{(1)}$ \\ The Custodian of the Two Holy Mosques Institute for Hajj Research, \\ Umm Al-Qura University, Makkah, Kingdom of Saudi Arabia \\ ${ }^{(1)}$ Air Pollution Department, National Research Center, Cairo, Egypt
}

Abstract. This study briefly aims to analyze the atmospheric BTEX pollutants (Benzene, Toluene, Ethylbenzene, o, m, p-Xylene for the first time in Makkah and Saudi Arabia. It was carried out at three sampling locations (Al-Shebakah, Al-Azizia, and Mina) during Hajj season $1431 \mathrm{H}$. Ambient air was adsorbed on adsorbent tubes and analyzed on GC-MS. The mean concentrations of benzene, toluene, ethylbenzene, and $\sum$ xylene in Al-Shebakah were $8.11 ; 15.85 ; 9.20$ and 8.45 , respectively, during day time and $31.44 ; 37.80 ; 42.03$ and $38.71 \mu \mathrm{g} / \mathrm{m}^{3}$ during night time, respectively. The measured values in Al-Azizia, were $11.75 ; 9.42 ; 18.8$ and 33.49 during day time, meanwhile, they were $4.78 ; 6.67 ; 8.45$; and $18.56 \mu \mathrm{g} / \mathrm{m}^{3}$, respectively during night time. The third location Mina, the obtained values were $3.16 ; 8.07 ; 6.20$; and 5.55 during day time and $34.03 ; 52.39 ; 35.52$; and $64.51 \mu \mathrm{g} / \mathrm{m}^{3}$ during night time, respectively. The present study indicated that exposure to aromatic VOCs is to large extent influenced by different activities, weather conditions and diurnal variation in Makkah. In conclusion, the high levels of VOCs in the holy city are sufficient to represent a degree of risk to the pilgrims as well as the local populations and a more comprehensive studies all over the year would be required for better quantifying the problem.

Keywords: Ambient volatile organic compounds $\left(\mathrm{VOC}_{\mathrm{S}}\right)$, Benzene, toluene, Ethylbenzene, Xylene, The Holy City of Makkah.

\section{Introduction}

Urban air pollution is rapidly becoming an environmental problem of public concern from the last few decades. Volatile organic compounds 
(VOCs) are a major group of pollutants, which have now become a cause of concern worldwide. VOCs are harmful to ecosystem, human health and atmosphere. Many VOCs like benzene and tetrachloroethylene have been proved to be a potent carcinogen (USEPA, 1990). Sources of VOCs emission are both anthropogenic and natural. It is thus essential to control anthropogenic emissions of VOCs. Volatile organic compounds (VOCs) are one of the most important groups of air pollutants in the urban atmosphere because they can cause significant risk to human health. Many VOCs have been reported to be toxic, carcinogenic or mutagenic (Edgerton et al., 1989; Sweet and Vermette, 1992). In addition, the presence of VOCs in the atmosphere play an important role in the formation of ground level ozone, photochemical oxidants and smog episodes (Monod et al., 2001). The major anthropogenic sources in the urban environment are vehicle exhaust, gasoline evaporation, emissions from the use of solvents, and gas leakage from natural gas and liquefied petroleum gas (LPG). The levels of VOCs in the ambient air are related to the fuels used, vehicle types and ages, flow rates and speeds of traffic as well as road and environmental conditions in the city (Hsieh and Tsai, 2003). The increased aromatics, olefins and other organic compounds in fuels used in vehicles lead to an increase in the emission of aromatic VOCs, especially from vehicles which are not supplied with catalytic converters (Hsieh and Tsai, 2003).

Among the aromatic volatile hydrocarbons; benzene, toluene, ethylbenzene and xylenes (BTEX). Xylenes are considered the more reactive species with respect to ethylbenzene, whereas benzene has a lower reactivity and more stable in the atmosphere, due to its relatively longer lifetime (Hsieh and Tsai, 2003). BTEX compounds are created and used during the processing of petroleum products and during the production of consumer goods such as paints and lacquers, thinners, rubber products, adhesives, inks, cosmetics and pharmaceutical products. BTEX compounds are among the most abundantly produced chemicals in the world (Buczynska et al., 2009).

Makkah received Millions of pilgrims every year to perform Hajj and/or Umrah. More than 13 million Muslims visit Makkah annually. Increasing of pilgrims numbers is accompanied by the increase of their daily activities as well as the increase demands of transportation means. These can cause serious air pollution problem, especially in urban areas, due to rapid urbanization and motorization. Previous studies of outdoor 
pollutants have focused on the primary criteria pollutants. The lack of monitoring data for other pollutants has affected the ability of scientists to study the exposure to other air toxins, which include e.g., a group of volatile organic compounds; Benzene, Toluene, Ethylbenzene, o, m, pXylene (BTEX). These are an important class of aromatic pollutants due to their harmful potential and their strong correlation with motor vehicle exhaust emissions. Moreover, xylenes ((m, p)-xylene plus o-xylene) are the most dominant contributor to ozone formation among BTEX ( $\mathrm{Na}$ et al., 2005). The (m, p)-xylene/ethylbenzene concentration ratio is used to investigate the extent of photochemical reactivity in the atmosphere and to estimate the photochemical age of air mass (Nelson and Quigley, 1984; Monod et al., 2001; and Hsieh and Tsai, 2003).

The present study aims to measure the ambient levels of BTEX in three sampling locations and study the spatial and temporal variations of these pollutants at the most important locations in Makkah (Al-Shebakah, Al-Azizia, and Mina) during hajj season1431H. It is considered as the first type of such studies in Saudi Arabia. It is a part of the plan designed by The Custodian of the Two Holy Mosques Institute for Hajj Research, Umm Al-Qura University to investigate VOCs air quality over whole Makkah.

\section{Materials and Methods}

\section{Study Area}

The Holy City of Makkah (Latitude $1925^{\circ} 21$ North Meridian 46 $49^{\circ} 39$ ) is at an elevation of $277 \mathrm{~m}(910 \mathrm{ft})$ above sea level, and approximately 50 mile $(80 \mathrm{~km})$ inland from the Red Sea. The city is situated between mountains, which have defined the contemporary expansion of the city with a population of 1,700,000 (Central Department of Statistics and Information, 2008). The city centers around the Masjid al-Haram area, whose altitude is lower than most of the city. The area around the mosque comprises the old city.

Transportation facilities related to the Hajj and/or Umrah are the main services available around the city are either personal vehicles or private taxis.

Three sampling locations were selected in the present study as shown in Fig. (1). The ambient air samples were collected from the 
selected sites (Al-Shebakah near to Harm; Al-Azizia; and Mina) to represent the whole activities in the selected areas during Hajj season $1431 \mathrm{H}$.

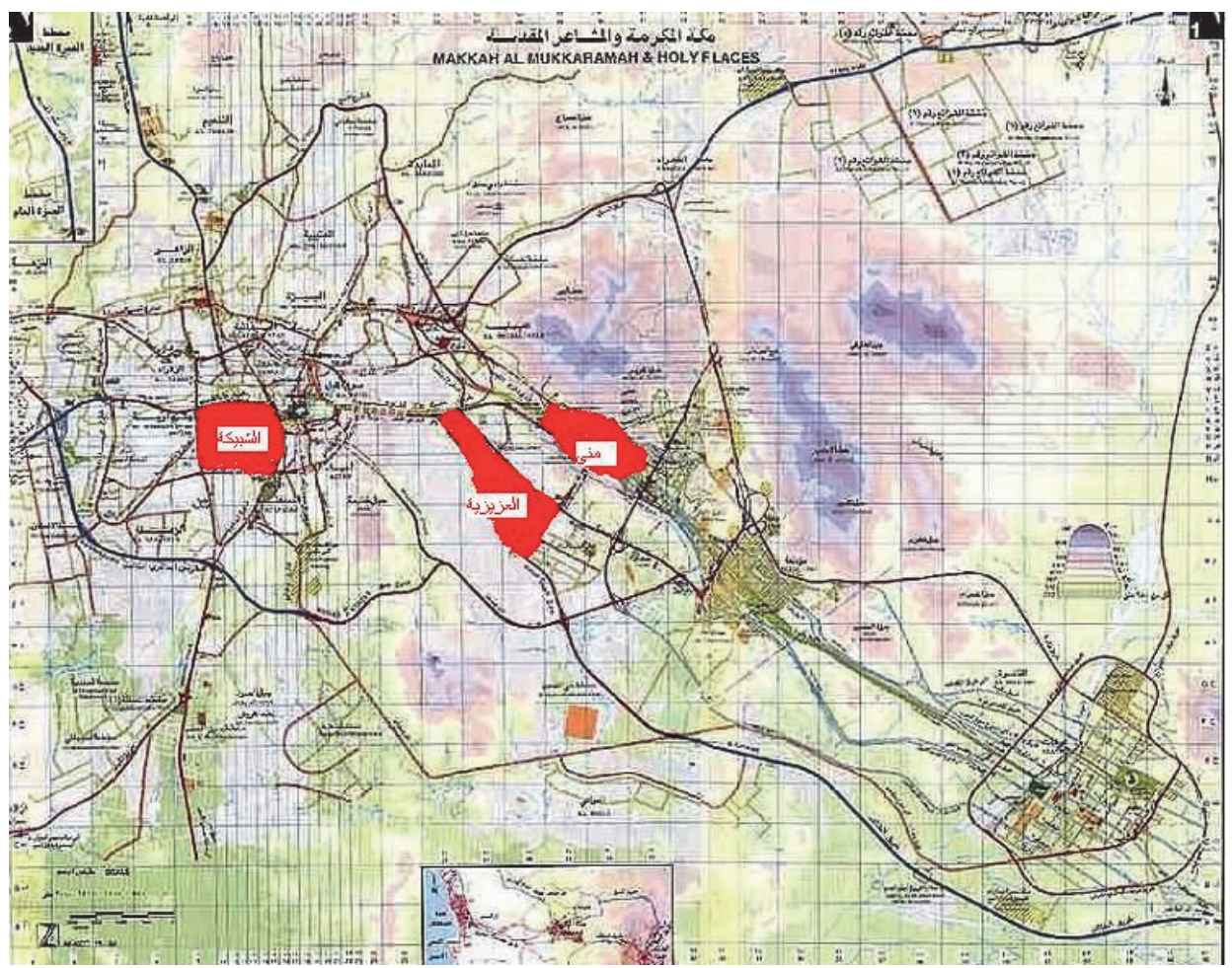

Fig. 1. Map of Makkah showing the sampling locations.

\section{Sampling and Analysis}

Ambient VOCs samples were collected according to a standard method developed by NIOSH (1996) using activated charcoal tubes (ORBOTM-32 activated coconut charcoal (20/40)) for the collection (NIOSH, 1996; Khoder, 2007). The collection tubes (Supelco, Inc., Bellefonte, PA) contained $150 \mathrm{mg}$ of coconut charcoal sub-divided into two portions of 100 and $50 \mathrm{mg}$ : the front portion of $100 \mathrm{mg}$ was used to collect the VOCs, while the $50 \mathrm{mg}$ backup section was intended to determine if solvent breakthrough occurred from the front section. Air was drawn through the charcoal tubes, using a pump calibrated to draw $0.20 \mathrm{~L} / \mathrm{min}$. After sampling, close the tubes, wrap them in foils and identify them by labels. Process the samples in the shortest run. 
Maximum duration time in refrigerator is 5 days, separated from other samples.

During the sampling procedure, one charcoal tube was opened at the sample site and then the ends capped, which served as a blank. The samples and blank tubes were put into special plastic bags that were tightly closed and kept at $-10{ }^{\circ} \mathrm{C}$ in a freezer until analysis, not more than 15 days.

BTEX compounds are extracted from activated charcoal using $1 \mathrm{ml}$ carbon disulphide $\left(\mathrm{CS}_{2}\right)$. Operational parameters are optimized and quantitative recovery is obtained using $\mathrm{CS}_{2}$ as the extraction solvent (NIOSH, 1996; and Khoder, 2007). Determination of BTEX compounds is carried out by gas chromatography using a flame ionization detector (GC/FID).

\section{Results and Discussion}

Statistical analysis of most abundant group of VOCs (BTEX); Benzene, Toluene, Ethylbenzene, and $\sum$ Xylene in the three studied locations are shown in the Tables (1-6). They were $8.11 ; 15.85 ; 9.20$; $8.45 \mu \mathrm{g} / \mathrm{m}^{3}$ during day time and $31.44 ; 37.80 ; 42.03$ and $38.71 \mu \mathrm{g} / \mathrm{m}^{3}$ at Al-Shebakahh during night time, respectively. At Al-Azizia, the values measured were $11.75 ; 9.42 ; 18.8$; and $33.49 \mu \mathrm{g} / \mathrm{m}^{3}$ during day time, meanwhile, were $4.78 ; 6.67 ; 8.45$; and $18.56 \mu \mathrm{g} / \mathrm{m}^{3}$, respectively during night time. BTEX concentrations were higher at Mina than those found in Al-Shebakah and Al-Azizia during night and lower during day time. The observed levels of BTEX in Al-Shebakah is due to the high traffic density, since this site is very close to Masjed Al Haram surrounded by many street intersections and roads leading to Haram in addition to the most commercial and heaviest traffic areas in Makkah.

Table 1. Concentration of BTEX $\left(\mu \mathrm{g} / \mathrm{m}^{3}\right)$ at Al-Shebakah during day time (9-12 AM).

\begin{tabular}{|c|c|c|c|c|c|c|c|c|c|}
\hline \multicolumn{10}{|c|}{ Al-Shebakah } \\
\hline Compound & $1-12-1431$ & $2-12-1431$ & $3-12-1431$ & $4-12-1431$ & $5-12-1431$ & Mean & Max. & Min & St.dev \\
\hline benzene & 11,72 & 4,38 & 3,76 & 9,8 & 10,9 & 8,112 & 11,72 & 3,76 & 3,76 \\
\hline toluene & 36,54 & 9,36 & 8,24 & 15,9 & 9,2 & 15,85 & 36,54 & 8,24 & 11,96 \\
\hline Ethylbenzene & 2,09 & 13,27 & 9,12 & 11,3 & 10,2 & 9,196 & 13,27 & 2,09 & 4,26 \\
\hline p-xylene & 4,19 & 2,27 & 4,64 & 3,9 & 4,5 & 3,9 & 4,64 & 2,27 & 0,96 \\
\hline o-xylene & 2,61 & 3,36 & 0,22 & 0,23 & 0,2 & 1,32 & 3,36 & 0,2 & 1,54 \\
\hline m-xylene & 2,96 & 5,45 & 0,24 & 4,3 & 3,2 & 3,23 & 5,45 & 0,24 & 1,94 \\
\hline
\end{tabular}


Table 2. Concentration of BTEX $\left(\mu \mathrm{g} / \mathrm{m}^{3}\right)$ at Al-Shebakah during day time (9-12 PM).

\begin{tabular}{|c|c|c|c|c|c|c|c|c|}
\hline \multicolumn{9}{|c|}{ Al-Shebakah } \\
\hline Compound & $1-12-1431$ & $2-12-1431$ & $3-12-1431$ & $5-12-1431$ & Mean & Max & Min & St.dev. \\
\hline benzene & 38,36 & 11,57 & 40,33 & 35,5 & 31,44 & 40,33 & 11,57 & 13,39 \\
\hline toluene & 51,09 & 6,52 & 52,77 & 40,8 & 37,80 & 52,77 & 6,52 & 21,51 \\
\hline Ethylbenzene & 73,91 & 10,15 & 41,55 & 42,5 & 42,03 & 73,91 & 10,15 & 26,03 \\
\hline p-xylene & 4,09 & 13,63 & 42,72 & 28,5 & 22,24 & 42,72 & 4,09 & 16,95 \\
\hline o-xylene & 4,99 & 13,64 & 4,96 & 2,3 & 6,47 & 13,64 & 2,3 & 4,94 \\
\hline m-xylene & 10,17 & 18,8 & 3,94 & 7,1 & 10,00 & 18,8 & 3,94 & 6,39 \\
\hline
\end{tabular}

Table 3. Concentration of BTEX $\left(\mu \mathrm{g} / \mathrm{m}^{3}\right)$ at Al-Azizia during day time (9-12 AM).

\begin{tabular}{|c|c|c|c|c|c|c|c|c|c|c|}
\hline \multicolumn{11}{|c|}{ Al-Azizia } \\
\hline Compound & $\begin{array}{l}6-12- \\
1431\end{array}$ & $\begin{array}{l}7-12- \\
1431\end{array}$ & $\begin{array}{l}8-12- \\
1431\end{array}$ & $\begin{array}{c}11-12- \\
1431\end{array}$ & $\begin{array}{c}12-12- \\
1431\end{array}$ & $\begin{array}{c}17-12- \\
1431\end{array}$ & Mean & Max & Min & St.dev. \\
\hline benzene & 10,36 & 2,1 & 44,84 & 5,51 & 5,9 & 1,8 & 11,75 & 44,84 & 1,8 & 17,63 \\
\hline toluene & 18,98 & 4,1 & 16,09 & 3,04 & 8,1 & 6,2 & 9,42 & 16,09 & 3,04 & 4,84 \\
\hline Ethylbenzene & 23,73 & 8,1 & 56,64 & 6,93 & 7,1 & 10,3 & 18,8 & 56,64 & 6,93 & 21,07 \\
\hline p-xylene & 21,18 & 11,7 & 2,54 & 3,78 & 12,3 & 12,9 & 10,73 & 12,9 & 2,54 & 3,87 \\
\hline o-xylene & 20,45 & 14,2 & 35,87 & 7,06 & 3,5 & 20,2 & 16,88 & 35,87 & 3,5 & 12,72 \\
\hline m-xylene & 4,44 & 2 & 18,98 & 6,18 & 0,9 & 2,8 & 5,88 & 18,98 & 0,9 & 7,08 \\
\hline
\end{tabular}

Table 4. Concentration of BTEX $\left(\mu \mathrm{g} / \mathrm{m}^{3}\right)$ at Al-Azizia during day time (9-12 PM).

\begin{tabular}{|c|c|c|c|c|c|c|c|c|c|}
\hline \multicolumn{10}{|c|}{ Al-Azizia } \\
\hline Compound & $6-12-1431$ & $7-12-1431$ & $8-12-1431$ & $11-12-1431$ & $12-12-1431$ & Mean & Max & Min & St.dev. \\
\hline Benzene & 0,49 & 11,6 & 3,35 & 6,72 & 1,75 & 4,78 & 11,6 & 0,49 & 4,47 \\
\hline Toluene & 2,34 & 7 & 15,18 & 6,98 & 1,87 & 6,67 & 15,18 & 1,87 & 5,35 \\
\hline Ethylbenzene & 9,01 & 18,5 & 3,34 & 8,54 & 2,88 & 8,45 & 18,5 & 2,88 & 6,29 \\
\hline p-xylene & 3,43 & 12,2 & 17,27 & 0,89 & 0,2 & 6,80 & 17,27 & 0,2 & 7,56 \\
\hline o-xylene & 0,3 & 15,8 & 14,09 & 3,82 & 0,02 & 6,81 & 15,8 & 0,02 & 7,60 \\
\hline m-xylene & 0,28 & 10,5 & 11,63 & 2,09 & 0,23 & 4,95 & 11,63 & 0,23 & 5,65 \\
\hline
\end{tabular}

Table 5. Concentration of BTEX $\left(\mu \mathrm{g} / \mathrm{m}^{3}\right)$ at Mina during day riod time (9-12 AM).

\begin{tabular}{|c|c|c|c|c|c|c|c|c|}
\hline \multicolumn{9}{|c|}{ Mina } \\
\hline Compound & $8-12-1431$ & $9-12-1431$ & $10-12-1431$ & $12-12-1431$ & Mean & Max & Min & St.dev. \\
\hline benzene & 0 & 2,58 & 3,93 & 6,13 & 3,16 & 6,13 & 0 & 2,56 \\
\hline toluene & 19,14 & 2,86 & 6,13 & 4,13 & 8,07 & 19,14 & 2,86 & 7,51 \\
\hline Ethylbenzene & 12,78 & 0,02 & 6,34 & 5,65 & 6,20 & 12,78 & 0,02 & 5,22 \\
\hline p-xylene & 0,02 & 3,69 & 2,96 & 0,02 & 1,67 & 3,69 & 0,02 & 1,93 \\
\hline o-xylene & 0,02 & 1,82 & 2,91 & 0,02 & 1,19 & 2,91 & 0,02 & 1,43 \\
\hline m-xylene & 0,02 & 0,63 & 10,09 & 0,02 & 2,69 & 10,09 & 0,02 & 4,94 \\
\hline
\end{tabular}

Table 6. Concentration of BTEX $\left(\mu \mathrm{g} / \mathrm{m}^{3}\right)$ at Mina during night time (9-12 PM).

\begin{tabular}{|c|c|c|c|c|c|c|c|c|}
\hline \multicolumn{9}{|c|}{ Mina } \\
\hline Compound & $8-12-1431$ & $10-12-1431$ & $11-12-1431$ & $12-12-1431$ & Mean & Max & Min & St.dev. \\
\hline benzene & 25,85 & 28,9 & 30,9 & 50,46 & 34,03 & 50,46 & 25,85 & 11,15 \\
\hline toluene & 60,54 & 55,8 & 50,5 & 42,71 & 52,39 & 60,54 & 42,71 & 7,64 \\
\hline Ethylbenzene & 35 & 34,8 & 32,9 & 39,36 & 35,52 & 39,36 & 32,9 & 2,73 \\
\hline p-xylene & 39,36 & 33,8 & 35,9 & 33,68 & 35,69 & 39,36 & 33,68 & 2,65 \\
\hline o-xylene & 24,09 & 22,6 & 25,8 & 24,69 & 24,30 & 25,8 & 22,6 & 1,33 \\
\hline m-xylene & 1,15 & 3,1 & 2,6 & 11,24 & 4,52 & 11,24 & 1,15 & 4,55 \\
\hline
\end{tabular}


The highest concentrations were recorded for benzene, toluene, Ethylbenzene, styrene, o-,m-,p-xylene almost during all monitoring days. Benzene is a carcinogenic compound causing leukaemia. WHO has estimated that a life time exposure of $1 \mu \mathrm{g} / \mathrm{m}^{3}$ of benzene leads to about six cases of leukaemia per million inhabitants (WHO, 1999). Toluene was recorded the highest concentration at Al-Shebekah site during daytime $\left(36.54 \mu \mathrm{g} / \mathrm{m}^{3}\right)$, while the highest concentration was reported in the same site during night-time for Ethylbenzene $\left(73.91 \mu \mathrm{g} / \mathrm{m}^{3}\right)$. Table 7 demonstrates the significant differences between the 3 different locations for both sampling periods (day and night). From the data listed in Table 7 , it can be noticed that the highly significant differences mostly observed in night time period between the 2 locations Al-Azizia and Mina in addition to Al-Shebakah and Mina.

Table 7. Differences between mean concentrations for concerned locations.

\begin{tabular}{|c|c|c|c|c|c|c|}
\hline T-Test & \multicolumn{3}{|c|}{ Day } & \multicolumn{3}{c|}{ Night } \\
\hline Compound & SH $\times \mathbf{A Z}$ & $\mathbf{S H} \times \mathbf{M E}$ & $\mathbf{A Z} \times \mathbf{M E}$ & $\mathbf{S H} \times \mathbf{A Z}$ & $\mathbf{S H} \times \mathbf{M E}$ & $\mathbf{A Z} \times \mathbf{M E}$ \\
\hline Benzene & $0.322 \mathrm{n} . \mathrm{s}$ & $0.030^{*}$ & $0.170 \mathrm{n} . \mathrm{s}$ & $0.002^{* *}$ & $0.388 \mathrm{n} . \mathrm{s}$ & $0.00^{* * *}$ \\
\hline Toluene & $0.143 \mathrm{n} . \mathrm{s}$ & $0.148 \mathrm{n} . \mathrm{s}$ & $0.385 \mathrm{n} . \mathrm{s}$ & $0.008^{* *}$ & $0.124 \mathrm{n} . \mathrm{s}$ & $0.00^{* * *}$ \\
\hline Ethylbenzene & $0.157 \mathrm{n} . \mathrm{s}$ & $0.186 \mathrm{n} . \mathrm{s}$ & $0.126 \mathrm{n} . \mathrm{s}$ & $0.023^{*}$ & $0.318 \mathrm{n} . \mathrm{s}$ & $0.00^{* * *}$ \\
\hline $\mathrm{p}$, xylene & $0.028^{*}$ & $0.028^{*}$ & $0.017^{*}$ & $0.054 \mathrm{n} . \mathrm{s}$ & $0.084 \mathrm{n} . \mathrm{s}$ & $0.00^{* * *}$ \\
\hline o-xylene & $0.008^{* *}$ & $0.449 \mathrm{n} . \mathrm{s}$ & $0.015^{*}$ & $0.471 \mathrm{n} . \mathrm{s}$ & $0.00^{* * *}$ & $0.001^{* *}$ \\
\hline m- xylene & $0.208 \mathrm{n} . \mathrm{s}$ & $0.414 \mathrm{n} . \mathrm{s}$ & $0.22 \mathrm{n} . \mathrm{s}$ & $0.124 \mathrm{n} . \mathrm{s}$ & $0.106 \mathrm{n} . \mathrm{s}$ & $0.453 \mathrm{n} . \mathrm{s}$ \\
\hline
\end{tabular}

$\mathrm{SH}=\mathrm{AL}-\mathrm{SHEBAKAH}, \mathrm{AZ}=\mathrm{AL}-\mathrm{AZIZIA}, \mathrm{ME}=\mathrm{MINA}$

$*=p<0.05, * *=p<0.01, * * *=p<0.001, \mathrm{n} . \mathrm{s}=$ Non Significant

As to AlShabaka and AL-AZIZIA, the highest concentration for the night was reported for toluene $\left(60.54 \mu \mathrm{g} / \mathrm{m}^{3}\right)$ on the same date. Similar to the other sites, benzene, toluene, Ethylbenzene, o-,m-,p-xylene were the major compounds among VOCs. This may be due to some local activity during the period of monitoring.

The current study illustrates that benzene, toluene, Ethylbenzene, and o-,m-,p-xylene were the major VOCs compounds which were monitored in Al Azizya either during the days or the nights. While the higher concentration during the days was reported for ethylbenzene, the lowest day concentration was reported during 7-12-1431, and the lowest night concentration was for 12-12-1431.

Comparing the current study with other reported ones around the world e.g., in a Canadian study (Wallace, 1996) found that benzene concentrations were reported as well for ambient air samples collected from 10 Canadian cities. The overall mean was $4.4 \mu \mathrm{g} / \mathrm{m}^{3}$. On the other 
hand, in rural sites the author reported concentrations ranging from 0.6 to $1.2 \mu \mathrm{g} / \mathrm{m}^{3}$. In Italian urban areas air pollution from benzene is mostly caused by traffic. The concentration limit in the atmosphere fixed by Italian legislation up to December 31, 1998 expressed as annual mean is $15 \mu \mathrm{g} / \mathrm{m}^{3}$ and, starting from January $1,1999,10 \mu \mathrm{g} / \mathrm{m}^{3}$ (Bini et al., 1998). All above studies are less than the current findings. Therefore, the current data showed that the level of BTEX are high and stress the need for regular monitoring program for these hazardous air pollutants.

\section{Conclusions}

1. Among BTEX group, benzene has been detected in the present study with considerable concentration comparing to other studies carried out in different parts of the world. Therefore, this group of VOCs has received much attention in exposure assessment studies.

2. The results of such study, in combination with information on time activity patterns can be used to establish population exposure distributions for VOCs if a large enough number of sites have been studied.

3. The current study indicated that exposure to aromatic VOCs is to a large extent influenced by different activities in the Holy city, weather conditions, and diurnal variation.

4. Data rising from this study illustrated that the high levels of VOCs in Makkah are sufficient to represent a degree of risk to the local population and a more comprehensive study over a long period of time and during the four seasons of the year would be required to better quantifying the problem.

5. It is necessary to adopt drastic measures concerning motor vehicles, either by reducing traffic or introducing emission control devices, to reduce the ambient levels of VOCs in Makkah.

\section{References}

Bini, G., Di-Vaio, V., Liguori, E., marini, E. and Pagliai, L. (1998). Carcinogens in the urban environment of Italian cities: benzene and benzo(a)pyrenes. Med-Lav, 89: 177-87 (In Italian, the abstract in English).

Buczynska, A., Krata, A., Stranger, M., Godoi, A., Kontozova-Deutsch, V., Bencs, L., Naveau, I., Roekens, E. and Grieken, R. (2009). Atmospheric BTEX concentrations in an area with intensive street traffic. Atmospheric Environment, 43: 311-318. 
CB. (2010). Chemical Book. http://www.chemicalbook.com/Chemical Product Property EN_ CB9245073.htm.

Central Department of Statistics and Information. (2008). Saudi Arabia.

Clyde, W. and Vermette, S. (1992). Toxic volatile organic compounds in urban air in Illinois. Environmental Science and Technology 26: 165-173.

Chemicalland, (2010). http://www.chemicalland21.com/industrialchem/organic/ MDICHLOROBENZENE.htm.2010.

Edgerton, S.A., Holdren, M.W. and Smith, D.L. (1989). Inter-urban comparison of ambient volatile organic compound concentrations in US cities. Journal of Air Pollution and Control Association 39: 729-732.

Hsieh, C.C. and Tsai, J.H. (2003). VOC concentration characteristics in Southern Taiwan. Chemosphere 50: 545-556.

Khoder M.I. (2007). Ambient levels of volatile organic compounds in the atmosphere of Greater Cairo, Atmospheric Environment 41: 554-566

Monod A., Sive, B.C., Avino, P., Chen, T., Blake, D.R. and Rowland, F.S. (2001). Monoaromatic compounds in ambient air of various cities: a focus on correlations between the xylenes and ethylbenzene. Atmospheric Environment 35: 135-149.

Na, K., Moon, K.C. and Kim, Y.P. (2005). Source contribution to aromatic VOC concentration and ozone formation potential in the atmosphere of Seoul. Atmospheric Environment 39: $5517-5524$.

Nelson, P.F. and Quigley, S.M. (1984). The hydrocarbon composition of exhaust emitted from gasoline fueled vehicles. Atmospheric Environment 18: 79-87.

NIOSH. (1996). Method 2549 in the NIOSH Manual of Analytical Methods, fourth ed. US Department of Health and Human Services, Center for Disease Control, NIOSH; Cincinnati, OH. May 15, 1996.

USEPA. (1990). Cancer Risk from Outdoor Exposure to Air Toxics, PA-450/1-90-004a. Research Triangle Park, NC, Office of Air Quality Planning and Standards

Wallace, L. (1996). Environmental exposure to benzene: An update. Environ. Health Perspec. 104 (Suppl 6): 1129-1136.

World Health Organization (WHO) (1999). Air Quality Guidelines for Europe. WHO Regional Publication, European Series. World Health Organization. Regional Office for Europe, Copenhagen. 


\section{تحديد مركبات البي تي إكس الملوثة للهواء في مدينة مكة المكرمة}

\section{تركي محمد حبيب الله، و محمود عبد المجيد حسانين}

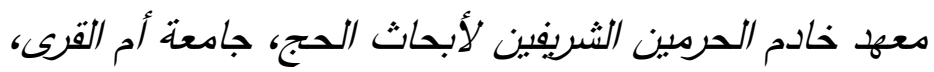
مكة المكرمة - المدلكة العربية السعودية

* المركز القومي للبحوث، القاهرة - جهورية مصر العربية

الدستخلص. تهتم هذه الدراسة بتحليل مركبات البيتيكس في الهواء وهـي البنزين والطولين والإثيلـي بنـزين ومركبـات الـزيلين. وتعتبر

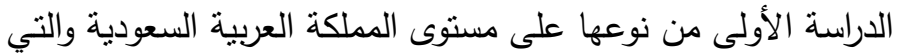
تم إجراؤها على ثلاث مواقع (الثبيكة - العزيزية - منىى) في مكة الثنة

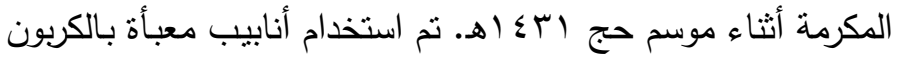
النشط لنكون بيئة جيدة لامتصاص تلك المركبات بواسطة مواطير

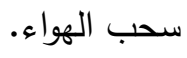

وقد سـجل متوسط تراكيز البنزين والطولين والإثيلي بنزين

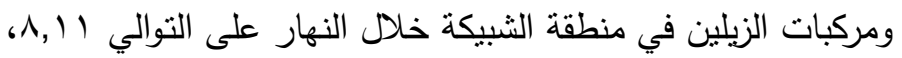

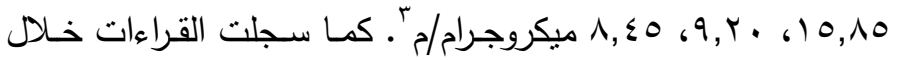

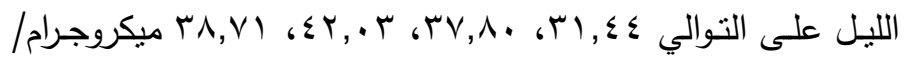

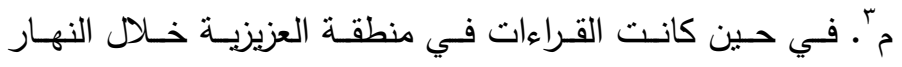

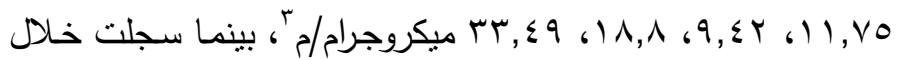

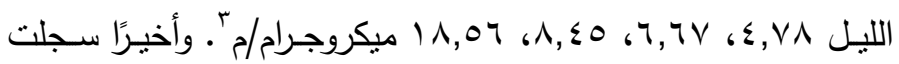

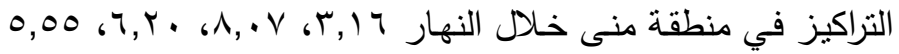




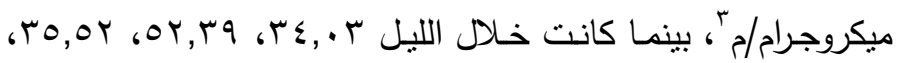

$$
\text { • }
$$

كما تمثل الدراسة الحالية النواة الأولى للبدء بمعرفة تعرض هذه الملوثات على الحجـاج والمـواطنين في ظل تعدد الأنشطة البشـرية وتقلبات الطقس خلال البوم في مكة المكرمة. لذلك استتتج الباحثون بأن مقدار التعرض لهذه الملوثات محل اهتمام الدراسات المستقبلية لمعرفـة زمـن التعرض بالمقارنـة مـع حجم تركيز تلك الملوثات في الهواء وبالتالي حساب أثز الملوثات على صحة الإنسان.

الكلمات الدالة: المركبـات العضـوية المتطــايرة، البنـزين، الطــولين، الإيثنيلي بنزين، الزيلين وَمكة. 